$A D D I N$, Volume 12, Number 2, Agustus 2018

\title{
INTEGRATION OF ISLAM AND PENDHALUNGAN CULTURAL VALUES AS A RELIGIOUS TOLERANCE ATTITUDE
}

\section{Ilfiana Firzaq Arifin}

Graduate History Education, Universitas Sebelas Maret Surakarta ilfianafirzaq@gmail.com

\author{
Akhmad Arif Musaddad \\ Graduate History Education, Universitas Sebelas Maret Surakarta \\ arif_mussadad_fkip@yahoo.co.id
}

\section{Sudiyanto}

Graduate History Education, Universitas Sebelas Maret Surakarta soeddie.fkipuns@gmail.com

\section{Abstract}

Diversity is the initial trigger of changing attitudes among individuals. The attitude change can be negative or positive, depending on each individual whether to menfilter anything that indicates the creation of a change of attitude towards a positive or negative. Writing this article aims to provide an overview of male and female students of SMK Plus Nurul Ulum were able to create a positive change in attitude towards the tolerance with teachings based on Islamic religious and cultural values Pendhalungan. The method used in this study is a qualitative method that is by conducting indepth interviews with some 
of the parties in the relevant schools. Then the data were also obtained from journals and literature support.

Keywords: Attitudes of Tolerance, The Teachings of The Islamic Religion, Cultural Values Pendhalungan.

\section{Abstrak}

Keanekaragaman adalah pemicu awal dari perubahan sikap di antara individu. Perubahan sikap bisa negatif atau positif, tergantung pada setiap individu apakah akan menfilter apa pun yang menunjukkan penciptaan perubahan sikap terhadap positif atau negatif. Penulisan artikel ini bertujuan untuk memberikan gambaran siswa pria dan wanita SMK Plus Nurul Ulum yang mampu menciptakan perubahan positif dalam sikapnya terbadap toleransi dengan ajaran berdasarkan nilai-nilai agama Islam dan budaya Pendhalungan. Metode yang digunakan dalam penelitian ini adalah metode kualitatif yaitu dengan melakukan wawancara mendalam dengan beberapa pihak di sekolah yang bersangkutan. Kemudian data juga diperoleh dari jurnal dan dukungan literatur.

Kata Kunci: Sikap Toleransi, Ajaran Agama Islam, Nilai-nilai Budaya Pendhalungan.

\section{A. Introduction}

Indonesian society has felt the changes in various aspects of community life, both in attitude, speech, behavior and so on ${ }^{1}$. Diversity is as a key trigger in changing people's attitudes. Indonesia is a unique nation state is characterized by its diversity as diversity of ethnicity, language, culture, religion and so on. From this uniqueness should be used as a strength for our nation to create a more humane attitude.

${ }^{1}$ Sairin, Sjafri, Perubahan Sosial Masyarakat Indonesia: Perspektif Antropologi (Yogyakarta: Pustaka Pelajar, 2002). 
As it has been explained by Hermawan ${ }^{2}$ that the changes appear in the aspect of social life can occur because of the diversity that miscommunication between individuals or groups in understanding the events that occurred in other regions.

The diversity of the community has the potential to give birth to the segmentation of the group, its structure is divided, weak consensus, often conflicting, forced integration, and their dominance of the group, resulting in a lack of space for public life that has implications for social change people's lives. This indicates that the community is less receptive and aware of the diversity that is present in the midst of their lives. Impact generate change the attitude of intolerance toward others.

Jember community can be regarded as a diverse community that is multicultural society and multi-ethnic, evidenced by the origins of the people who were born from ancestors of different cultures and ethnicities, namely Java, Madura, Chinese, Arabic and Osing. Multicultural and multi-ethnic basis is the background of the creation of community Jember create a new culture that is culture Pendhalungan which is composed of diverse cultures and ethnic communities framing Jember.

Jember contemporary society first, rated as a society that is tolerant of diversity whether it's to race, ethnicity, religion, race and so on. But these days the public image of Jember formerly known as friendly societies, mutual love, mutual tolerance, polite and civilized good layer of folk and political elite had almost ceased to exist. This is most

${ }^{2}$ Wawan Hernawan, "Social Prejudice In Religious Plurality At Cigugur District Regency of Kuningan West Java," Journal of Social Sciences and Humanities 19, no. 1 (2017), $77-85$. 
likely due to the process of transformation from traditional towards modern life or commonly called modernization.

Basically, the notion of modernization includes a total transformation of co-existence of traditional or pre-modern in terms of technology and social organization towards patterns of economic and political became the main feature of western countries are stable. Modernization is a form of social change. Usually a purposeful social change, which is based on a planning method called social planning. Rogers ${ }^{3}$ interpret modernization is a process by which individuals can change the traditional way of life to lifestyles that are more complex and advanced, and rapidly changing. Eisenstadtd ${ }^{4}$ point about modernization. He said that modernization is a joint copaced world of modern although disrupt the unity that had been embedded for life in modernity. Modernization is a problem that must be faced by the community concerned because the process includes areas of very broad, involves a process of disorganization, social problems, conflicts between groups, the barriers to change and so on. Usually people who have common characteristics described by the term modernization of social mobility, means a process of socio-economic elements and psychological starting to show opportunities towards new patterns through socialization and behavior patterns. Manifestations are aspects of modern life such as urbanization, mechanization, Regular mass media and so on. While the social aspects sturktural social organization is defined as the elements and societal norms are realized when humans make contact with each other in social life. These structural changes may involve social institutions, societal norms, social strata, relationships and so on. From

${ }^{3}$ Everett M Rogers, Modernization Among Peasants: The Impact of Communication (New York: Holt, Rinehart, and Winston, 1976).

${ }^{4}$ S.N Eisenstadtd, Modernization: Protest and Change (englewood cliffs: prenticehall, 1966). 
such understanding can be concluded that the real man is the creature who always want to change themselves. Changes in human beings usually follow the pattern of the prevailing circumstances in which he lived. But with this modernization, human beings can choose the path from anywhere and do anything for him to be and referred to as a modern human. This means that the actual modernization invites people to build a negative attitude. Supposedly with modernization can bring people to build a more positive attitude and have a very great use value for its survival period to the next.

Along with it, the real modernization invites people to build another side of his character in a positive direction, turns out to have negative impacts as well which is quite unusual for the community and among students in Jember. Various kinds of violence and social conflict that led to the birth of new movements that carry the name of religion as a backdrop and a base in the act almost entirely in Jember.

Beritajatim.com ${ }^{5}$ proclaim their report to the GP Ansor stating that there is a group of Islamic-based religious sects preach to blame the religious rituals of society (such as tahlil) in Gladak Pakem subdistrict Sumbersari and Sweet Land, as well as Silo Subdistrict Jember. They assume that Tahlil an unlawful activity and heresy in Islam, so it can not be done. Then launch also of dailykompas.com ${ }^{6}$ notes that there are five religious conflicts that occur in Jember. Furthermore, in the news Halim, who serves as chairman of the MUI Jember mention that the five conflict keagaaman appearing in Jember which comes from ideologys to emerging lately in Jember such as ideology Qodriyatul Qosimiyah, Indonesian

${ }^{5}$ Beritajatim.com, "Waspadai Dakwah Intoleran, MUI Jember Segera Temui GP Ansor," 2018.

${ }^{6}$ Kompas.com, "MUI: 2013, Lima Konflik Keagamaan Terjadi Di Jember," 2013. 
Islamic Propagation Institute (LDII), the ideology of boarding Rabbani, the ideology of the College Dirosah Islamiyah (STDI) Imam Shafi'i, and conflict in the village Syia'ah Puger Puger Kulon subdistrict. Other religious-based intolerance cases that have occurred in Jember that clashes between Sunni vs Shia as in the reports of VOA-Islam.com ${ }^{7}$ reported that have been clashes between religious sects in the village of Jember namely Puger Kulon District of Puger between the ideology of Sunni vs Syi'ah Islam that causes one person fatalities.

Religious nuances related social conflicts that occur in various areas, including that caused by religion in public life is a sensitive matter, so that through the religious sentiments of a person or group of people psychologically easily mobilized and utilized by groups in conflict for support. Bruinessen ${ }^{8}$ said that the sectarian violence in Indonesia is one of the serious problems and become a new phenomenon that is most striking in the current politics in Indonesia. While the main causes of conflict in general the non-religious, political, economic and cultural.

Rampant cases of intolerance between religions being spread Jember community lately a horizontal cases which are sometimes difficult to resolve. The difficulty of dispute resolution horizontal religion among the people can be triggered from the sturdy stance held by the respective religions and denominations. So that's where their base an argument to be strong and difficult conflict to be muted. There are government efforts to overcome it, say they fielded religious experts, police, and the holders of power as a third party in resolving inter-religious conflict in Jember.

${ }^{7}$ VOA-Islam.com, "Habib Zein Alkaf: Bentrok Di Jember adalah Konflik Sunni vs Syi'ah," 2013.

${ }^{8}$ Martin van Bruinessen, "Genealogies of Islamic Radicalism in Post-Suharto Indonesia," South East Asia Research 10, no. 2 (2002), 117-54. 
The rise of the current case illustrates that people in Jember already have a strong faith in religion and does not have a social value that tertananam in particular culture of tolerance towards others. So the relationships between people are not as beautiful as the first. She lacked tolerance in the hearts of every society is heterogeneous, causing concern is high enough to see these changes lead to changes in the values of life that are contrary to the values of religion and culture of the noble nation. The values contained in the noble nation of religion and culture is an important foundation in social life and religion. Besides religious and cultural values of the noble nation is a strong identity to introduce ourselves to the outside world,

Islamic religious and cultural values, especially the noble nation Pendhalungan embedded culture and invested by the predecessor are highly effective in affecting the joints of the social community in Jember. If people Jember realizing it, they should have strengthened the faith and confidence in the values of cultural and practiced in real life in order to avoid events that are not expected as protracted conflicts and tragedies of the human rights violations, especially in trust religious.

To avoid the spread of the virus of intolerance that was infecting people Jember lately, students and students of SMK Plus Nurul Ulum orphanage always apply what is taught in their religious and cultural values Pendhalungan to daily activities in school, such as mutual aid, tolerance, solidarity, social care, care for the environment and so on. This is because they realize that they are students coming from different cultural backgrounds, although they are a religion and is currently in the same pot that is SMK Plus Nurul Ulum. In addition, the background of the creation of tolerance in the school that is the desire to create harmony 
and harmony in the body of a school that is being particularly on the desire of each school community, maupaun wider community. Harmony school community is intended as a situation where the institutions are located to the school as principal institutions actually function and complement each other. So that in such circumstances the individual psychologically will feel the tranquility in the absence of opposition in the norms and values.

Plus SMK Nurul Ulum is based boarding school, located in one of the villages in the district of Jember Panti. Although the basis of Islamic boarding schools attached to him, there is no doubt they do not care about the other people of the same religion but have different ideology, as well as to others of different denominations from his base. Has many activities undertaken to implement the attitude of religious tolerance through activities of social, religious and so on. It makes SMK Plus Nurul Ulum as a school that is able to build a fortress strong religious tolerance attitude to avoid transmission of the virus that was endemic religious intolerance among people of Jember.

The purpose of writing this article is to describe the attitude of religious tolerance of students of SMK Plus Nurul Ulum based on the teachings of Islam and the cultural values Pendhalungan Jember. This is a proof that tolerance is indispensable, especially in respect of a difference in the heterogeneity of the pot so that there will be no more divisions and various conflicts that arise as a result of their differences.

This research was conducted at SMK Plus Nurul Ulum Panti, Jember. This school is based boarding school, located in one of the villages in the district of Jember Panti. This study uses a qualitative method by digging the oral information related to the research topic as much as possible. Informants 
were used in this study is from the school SMK Plus Nurul Ulum ie principals, teachers, and students involved. Data were collected by interview, observation and documentation. In addition, data were also obtained from the literature a wide range of journals and books supporting literature.

\section{B. Discussion}

\section{Historical Background of Students At SMK Plus Nurul Ulum}

Plus SMK Nurul Ulum is a school located in one of the village in the district of Panti, Jember. This school is based boarding school of Islam that stood from 2007 until now. This school is a private vocational schools that provide vocational dressmaking. Which is owned by the school students are students who come from the environment around the school in the village of Panti subdistrict Kemungsarilor and from remote villages Argopuro slope of the mountain like Dusun Karang Pakel, Badean Desa, Desa Pakis, Hamlet Berek Sabe, Widodaren Hamlet, and Hamlet Laok Songai.

The incorporation of students into the vocational Plus Nurul Ulum from various regions, lead to the creation of heterogeneous multicultural students, because in each region holds the tribal / ethnic itself. Examples Hamlet Laok Sabe donate Madurese students, and students who donated Kemuningsarilor village of Javanese ethnicity. Ethnic / tribal decorate SMK Nurul Ulum Plus is the majority of Java and Madura, although there are some small ethnic Arabs which only accounts for `35\% only.

Differences in the historical background of ethnic / tribal coloring vocational students Plus Nurul Ulum, does not influence the differences in religion. They still remain in the belief that the religion of Islam. However, differences in the historical background of tribal / ethnic cause differences to 
understand the ideology of the Islamic religion they believe in like Muhammadiyah, Nahdlatul Ulama, and Yahuk (Jehuk in Madurese). Rohman's said that every religious sects in Islam carry and give birth to the ideology of its own but still take shelter and breath of Islam. In accordance with this opinion, it is in Islam innumerable streams which appear in each of these streams carry a very good understanding to be taught to his followers. The following will explain a few understood the religious streams carried by each male and female students in vocational Plus Nurul Ulum Panti, Jember:

\section{a. Nahdlatul Ulama}

Nahdlatul Ulama (NU) is anideology in the understanding of Islam was born in a traditional Islamic boarding schools, brought by KH. Abdul Wahab Hasbullah and KH. Hasyim Ashari ${ }^{10}$. Nahdalatul Cleric is one of the oldest Islamic organization in Indonesia ${ }^{11}$. NU is the largest Islamic organization of two Islamic organizations in Indonesia, namely Muhammadiyah ${ }^{12}$.

NU was founded in 1926 as an association of scholars in Indonesia ${ }^{13}$. More profound Nakamura explained that since almost half a century of the founding of this organization Nahdlatul Ulama, NU was transformed into the largest Islamic religious organization of this nature

${ }^{9}$ Abdul Rohman, "Persepsi Kelompok Syahadatain Terhadap Nilai-nilai Toleransi Di Kabupaten Banyumas,” Jurnal Analisa XVIII, no. 2 (2011), 273-83.

${ }^{10}$ Faisal Ismail, "The Nahdlatul Ulama Its Early History And Contribution To The Establishment of Indonesian State," Journal of Indonesian Islam 05, no. 02 (2011), 248-82.

${ }^{11}$ Mitsuo Nakamura, "The Radical Traditionalism of the Nahdlatul Ulama in Indonesia : A Personal Account of the 26th National Congress, June 1979, Semarang," South East Asian Studies 19, no. 2 (1981), 187-204.

${ }^{12}$ Robbin Bush, Nabdlatul Ulama and The Struggle for Power Within Islam and Politics in Indonesia (Singapore: ISEAS Publishing, 2009).

${ }^{13}$ Nakamura, "The Radical Traditionalism of the Nahdlatul Ulama in Indonesia : A Personal Account of the 26th National Congress, June 1979, Semarang." 
even though the organization is not a governmental or nongovernmental organizations.

NU adopts Ahl waljama'ah, which is a mindset that takes a middle way between to extreme aqli (rationalist) with the extreme naqli (skepturalis). Because the sources of Islamic law for NU not only the Qur'an and Sunnah, but also use the intellect coupled with empirical reality. How to think like that referred from earlier thinkers such as Abu AlHasan Al-Ash'ari and Abu Mansur Al Maturidi in theology/ monotheism of Godhead. Then in the field of jurisprudence more likely to follow the Shafi'i school of priests and recognize the other three schools of the Hanbali school of priests, imams and priests Hanafi Maliki. As illustrated in the NU 4-star emblem below. While in the field of Sufism developed methods of Al-Ghazali and Sheikh Al-Baghdadi Juneid integrating between Sufism Law.

The idea of returning to Khittah in 1984 was an important momentum to reinterpret the teachings of Ahlussunnah Wal Jama'ah (ASWAJA) and redefined the methods of thought, both in the field of jurisprudence and social. NU as well as redefined the relationship with the state. The movement succeeded again aroused thinking and social dynamics within NU.

NU has always participated actively in the process of human constructivist, with roots in the teachings Tawasuth, Tasamuh, tawazun and enjoining good and forbidding wrong ${ }^{14}$.Understanding the ideology of Nahdlatul Ulama is the ideology that has a lot of followers. KH. Hasyim has stated that the number of followers of $\mathrm{NU}$ in Indonesia as

${ }^{14}$ Moh Bahrudin, "Peran Ulama Nahdlatul Ulama Dalam Menyiarkan Paham Keagamaan Moderat Di Provinsi Lampung," Jurnal Analisis 17, no. 1 (2017), 43-64. 
many as 60 million people but Gus Dur estimated that more that more than $50 \%$ of Indonesia is Nahdliyin ${ }^{15}$.

SMK Plus Ulum as much as $60 \%$ of students of classes X-XII understand the ideology of the Nahdlatul Ulama (NU), so it can be concluded that this ideology is the ideology that dominates among male and female students of SMK Plus Nurul Ulum. However, it does not mean NU as ideas ideology most dominating religion in the school, not a lot of boys and girls who adopts other religious stream, but they also adopts another stream they think is correct.

\section{b. Muhammadiyah}

Muhammadiyah is not known as an ideology, but a movement that at first glance looks like a doctrinaire movement, but also at first glance looks like a systematic theological movement that uses the Qur'an and Sunnah as the basis of an emphasis on the moral and ethical aspects ${ }^{16}$. Muhammadiyah is one of the Islamic reform movement in Indonesia that began at the beginning of the 20th century, where at the time, was a period in the Middle East experienced changes brought such figures: Ibn Taymiyyah, Muhammad ibn Abdul Wahab, Jamaludin Al Afghani, Muhammad Abduh and Muhammad Rasyid Ridho. Muhammadiyah was born on 18 November 1912 to coincide Miladiyah on the 8th of Dhu al-Hijjah 1330 AH founded by KH Ahmad Dahlan in Yogyakarta. Unlike Muhammadiyah organization Nahdlatul Ulama which is a traditional organization. Muhammadiyah organization is a modern organization, reformist and updates. It can be symbolized that Muhammadiyah ideology is the

${ }^{15}$ Mohamad Sobary, NU dan Keindonesiaan Jakarta: Gramedia Pustaka Utama, 2010).

${ }^{16}$ Mutohharun Jinan, "Muhammadiyah Studies: Transformasi Kajian Tentang Gerakan Islam di Indonesia," Analisa Journal of Social Science and Religion 22, no. 02 (2015), 269-80. 
ideology that is fanatical in accordance with the opinion of the Raffles about Islam religion of fanatics.

However, Muhammadiyah is a large Islamic organization into two after the Nahdlatul Ulama. The organization's name is taken from the name of the Prophet Muhammad, so Muhammadiyah also may be known as people who become followers of the Prophet Muhammad. Muhammadiyah main objective is to return all irregularities that occurred in the process of propaganda. These deviations often lead to the teachings of Islam mixed-mixed blend in with the habits of certain areas for reasons of adaptation.

Muhammadiyah movement characterized by the spirit of building the social order and public education are more advanced and educated. Showing Islam is not just a religion is private and static, but dynamic and serves as a system of human life in all its aspects. In many Muhammadiyah formation reflects the commands of the Qur'an among the letter of Ali Imran verse 104. It explains that Muhammadiyah contains cues for movement of people in an organized way to explain Islamic propaganda, the people who move, which also contains an affirmation of life beroganisasi. Then in item 6 Preamble to the articles of association of Muhammadiyah reads "charity-launch efforts and struggle with organizational order which implies the importance of the organization as a necessary tool movement.

Muhammadiyah understood in SMK Plus Nurul Ulum considered a fanatic to understand, because of the teaching that is in contrast to the teachings understand proficiency level of understanding of the Nahdlatul Ulama and Yahuk. If the view of students course in vocational Plus Nurul Ulum already apparent that the ideology is a ideology fanatic Muhammadiyah which can be seen in terms of student performance and siswinya that look different from boys and 
girls who come from other streams such as NU and Yahuk. In terms of appearance, especially the students of SMK Plus Nurul Ulum who adopts Muhammadiyah seen more religious are characterized by long loose clothing and if your boss almost to half the length of the thigh, then a skirt that is in use has a width size. Other than that, headscarf they use also has its own characteristics usually measuring the width and thickness of the fabric so that the nakedness of hair does not look transparent from the outside. Apart from the appearance of one more thing that is evident in male and female students who adopts / ideology Muhammadiyah namely in terms of religion. From interviews with one of the students Saxon Muhammadiyah, he said that the teachings of religion in contrast to the teachings of Muhammadiyah ideology of NU and Yahuk ideology. For example, when somebody dies. For seven days and seven nights if a stream of scholars every day Nahdalatul do tahlilan bleak events in order to pray for the dead, but the ideology of Muhammadiyah it is not necessary. Apart from the appearance of one more thing that is evident in male and female students who adopts/ ideology Muhammadiyah namely in terms of religion. From interviews with one of the students Saxon Muhammadiyah, he said that the teachings of religion in contrast to the teachings of Muhammadiyah ideology of NU and Yahuk ideology. For example, when somebody dies. For seven days and seven nights if a stream of scholars every day Nahdlatul do tahlilan bleak events in order to pray for the dead, but the ideology of Muhammadiyah it is not necessary. Apart from the appearance of one more thing that is evident in male and female students who adopts/ideology Muhammadiyah namely in terms of religion. From interviews with one of the students Saxon Muhammadiyah, he said that the teachings of religion in contrast to the teachings of Muhammadiyah 
ideology of NU and Yahuk ideology. For example, when somebody dies. For seven days and seven nights if a stream of scholars every day Nahdalatul do tahlilan bleak events in order to pray for the dead, but the ideology of Muhammadiyah it is not necessary. For example, when somebody dies. For seven days and seven nights if a stream of scholars every day Nahdalatul do tahlilan bleak events in order to pray for the dead, but the ideology of Muhammadiyah it is not necessary. For example, when somebody dies. For seven days and seven nights if a stream of scholars every day Nahdalatul do tahlilan bleak events in order to pray for the dead, but the ideology of Muhammadiyah it is not necessary.

Unlike ideology NU, only $30 \%$ of students who embrace this genre, and most of them ethnic Arabs who live around the village of the District Rampibuji Rambipuji.

\section{c. Understand Yahuk (Jehuk)}

Not much is known about the ideology Yahuk (Jehuk). Almost never found a study that analyzes of this ideology. Yahuk ideology (Jehuk) is to say a new stream in Islam. This stream is a stream of Islam bernafaskan Java, so it can be said this ideology is the ideology of Javanese Islam.Hodgson ${ }^{17}$ states that Islam is the dominant force in the rites beliefs of Central Java and he also helped shape the character of social interaction and daily life of the whole society of Java. Furthermore, Hodgson also explained that Islam penetrated so quickly and deeply into the structure of Javanese culture because it is embraced by the palace as a base for Teoratik country.

Geert $^{18}$ in his book The Religion of Java explain views on Islam and Java are two different entities that are designed

${ }^{17}$ M Hodgson, The Venture of Islam. Conscience and History in a World Civilization, ed.(Chicago: University of Chicago Press, 1974).

${ }^{18}$ Clifford Geertz, The Religion of Java, III (Glencoe: The Free Press, 1960). 
separately, opposite and not compounded. Furthermore, he explained that Islam is contrasted with the Javanese who is seen as a romantic religion, archaic, and fascinating. If briefly described Islam and Java is the antonym. So that in turn, Islam in Java (Javanese Islam) is a popular religion is seen as a deviation from Islam. But unlike that described by Woodward about Islam and Javanese as has been described by Geertz above. Woodward ${ }^{19}$ show that Islam and Java compatible. If there is any conflict happened between the two, is something that is natural and fundamental Islam throughout history. Disagreement/conflict there is a classic problem that is very often the case in Islam. It can be used as a reference in Islam how to balance between the legal dimension and the mystical dimension between the container and the contents, between inner and outer. So thus the religion and the Javanese are Muslim because aspects of Islamic doctrine has replaced Hinduism and Buddhism as an axiom of Javanese culture and Javanese Islam here is seen as a variant reasonable in Islam and is entitled to be present as well as in Islamic India, Islamic Persia, Islam Malay and so on.

The ideology of this religion can be called a primitive religious sects, because things that are pleasing in this religious sects such as its shape, its teachings, attitudes espoused realized in the forms of rituals, mythology, etc. ${ }^{20}$ So the ideology of this religion is not an Islamic fanatic religious sects. However, unique to this genre is that they still breath the parent religion of Islam. Syari'at they hold is also an Islamic shariah. Syari'at codifies a set of norms and behavior that is taken from the Quran and Hadith. Both can shape behavior, obedience and submission. Meanwhile,

${ }^{19}$ Mark R Woodward, Islam Jawa, I (Yogyakarta: LKS Yogyakarta, 1999).

${ }^{20}$ A Singgih Basuki, Agama-agama Dunia: Agama Primitif(Yogyakarta: Jurusan Perbandingan Agama UIN Sunan Kalijaga Yogyakarta, 2012). 
scriptures used by Yahuk ideology are of the Qur'an and the Book which normally delves into the story menak (1001 nights). They also use the Hadith as part of the core of Islam. Together with the Koran, the Hadith and the book they believe they used to form the core of the normative Islamic law.

Of the many students who take science at SMK Nurul Ulum Plus, it was not a lot of students and students of SMK Plus Nurul Ulum's understand. Because the ideology is also not so much have members, and even the ideology is not so well known among the general public. Only 10\% say the least. Most of them come from the mountain slopes of Hamlet Berek Argopuro Sabe. Sabe Berek Hamlet is one of the hamlets in the village Badean are still included in the District Bangsalsari region. The majority of them come from the Madurese.

Table 1. Distribution of religious sects and ethnic student of SMK Plus Nurul Ulum

\begin{tabular}{|l|l|c|l|}
\hline \multicolumn{1}{|c|}{ territory } & \multicolumn{1}{|c|}{ tribe } & Religion & Religion ideology \\
\hline Village Badean & $\begin{array}{l}\text { Java, } \\
\text { Madura } \\
\text { and Arabic }\end{array}$ & Islam & $\begin{array}{l}\text { Nahdalatul } \\
\text { Ulama (NU) and } \\
\text { Muhammadiyah }\end{array}$ \\
\hline $\begin{array}{l}\text { Village } \\
\text { Kemuningsarilor }\end{array}$ & $\begin{array}{l}\text { Java and } \\
\text { Madura }\end{array}$ & Islam & Nahdlatul Ulama \\
\hline Hamlet Berek Sabe & Madura & Islam & Yahuk (Jehuk) \\
\hline $\begin{array}{l}\text { Hamlet Laok } \\
\text { Songai }\end{array}$ & Madura & Islam & Nahdlatul Ulama \\
\hline $\begin{array}{l}\text { Dusun Karang } \\
\text { pakel }\end{array}$ & Madura & Islam & Nahdlatul Ulama \\
\hline hamlet Widodaren & Madura & Islam & Nahdlatul Ulama \\
\hline Village Ramipuji & $\begin{array}{l}\text { Java, } \\
\text { Madura } \\
\text { and Arabic }\end{array}$ & Islam & $\begin{array}{l}\text { Muhammadiyah, } \\
\text { and Nu }\end{array}$ \\
\hline
\end{tabular}

Figure 1. Ideology Understanding Religion Students of SMK Plus Nurul Ulum 


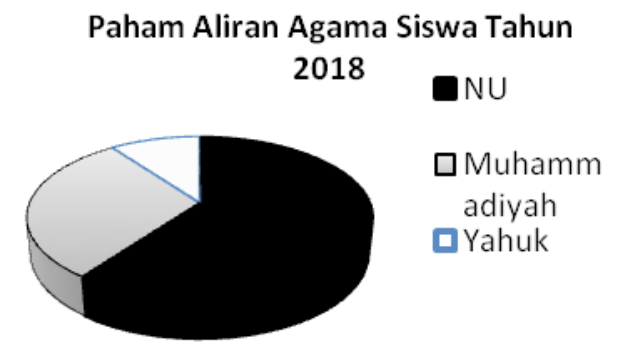

From partial understanding of Islam existing ideology, understand $\mathrm{NU}$ is understood that occupy the top position among students that is donated by $60 \%$. Then followed by Muhammadiyah by $30 \%$ and Yahuk (Jehuk) of $10 \%$. This description is similar to the percentage of the current understanding of religion believed by the public Jember. The majority of Jember embrace NU ideology as a stream that exist in Islam.

Although NU is understood that the most dominant in vocational Plus Nurul Ulum, male and female students who are continuing to build adopts a humble attitude control and balance in the face of diversity. Tolerance in religion always uphold them, because they mengaggap that religion is a part of human rights, they are free to choose their personal rights without coercion. As stated in the Qur'an Surah Al-Kafirun paragraph 6 "To you your religion and to me my religion". ${ }^{21}$ The verse has the meaning that humans are not allowed to force another human being into the teachings he believes in, such as religious teachings. They have been released for believing what they believe in this world. Because not necessarily what we believe is the right thing, it could be what we slander against those we forced to participate join the doctrine which we believe is not correct doctrine. This is in accordance with the Quran in Surah Al Hujurat verse 11

${ }^{21}$ Gagaje, "Surat Al Kafirun Lengkap Dengan Terjemahan dan Artinya," gagaje. blogspot.com, 2013, http://gagaje.blogspot.com/2013/05/surah-al-kafirun.html. 
which says "O ye who believe, do a bunch of men degrading another group, may be ridiculed it better than them. And do not also a bunch of other collection degrading women, probably lowered it better".

There are so many things we use as guidelines and flashbacks as a self learning process for everyone. However, unfortunately there is a feeling that what they believe and understand is the best thing so they never learn to appreciate others. In fact, if we probe further about the significance of the difference, the difference is the most wonderful thing if we understand it wisely. It is like a ideologyer garden in downtown consisting of various kinds of ideologyers are blooming together, no one wants to destroy one another because of a difference because they are aware of the differences in them will grow and prosper together in peace and spread the beauty and peace for everyone.

The existence of a difference whether it ideology, ethnicity, religion, race, sex and so forth is already commonplace in this world even this is a simphony which produces the sound of life of the blend a wide range of different tones. Interestingly, this is something that we are proud of, especially in the state of Indonesia is a nation of islands bebeda ranks were followed by diversity of ethnicity, religion, race, ethnicity and its own language. Natural nature determined by the supreme creation we can not deny. As in spoken by God in the Qur'an letter Ar-Rum verse 22 which reads "and among the signs of His power is to create the heavens and the earth and there sprang berlain language and skin color. Truly semikian it really artifacts are signs for those who know". Furthermore, Nur Cholis Majid in Barton $^{22}$ stated that human plurality is the fact that the Lord

${ }^{22}$ Greg Barton, Gagasan Islam Liberal Indonesia (Jakarta: Paramidana dan Pustaka Antara, 1999). 
desires. Furthermore, Allah also reinforce his words about the difference that as found in Surah Al Hujurat verse 13 which reads "O mankind! We created you from a male and a female, and made you nations and tribes that ye may know each other to know, Verily the noblest among you in the sight of Allah is the most pious among you. Indeed, Allah is Knower know".

Furthermore, the Qur'an states that differences of opinion or human rule should not be feared, but should be the starting point to compete for the better (Surah 5:48). Therefore, the difference is a natural law (the laws) that will not change and can not be denied. It can be concluded that the differences in the understanding of religion is the product of honest view against humanity inspired by mutual respect among individuals and groups.

Reflecting on the above, the Pancasila which is the ideology of the people of Indonesia in the first principle, namely on God also explained that that even in our nation is composed of different religions but have one God, and do not allow for any society to force other people to worship what they believe.

Clearly there that man was created with a difference, different tribes and nations so that they can recognize each other so it does not arise embers of hatred against fellow human beings.

\section{Culture of SMK Plus Nurul Ulum}

Culture is closely connected to the community, although the nature of the actual culture is abstract. But culture produces a form that is the form of objects created by man as a creature of culture, in the form of a pattern of behavior, language, equipment life, social organization, religion, art, and others, all of which was shown to help humans in the hold of the life of society. 
Geertz $^{23}$ defines culture is human knowledge that is believed to be true by the person concerned and covered and enveloped the feelings and emotions of human as well as a source for the assessment system is something that is good and bad, something valuable or not, something is clean or dirty, and so. This can happen because the culture was shrouded by moral values derived from moral values are a way of life and the ethos or ethical system in possess every human being.

Culture has become a system of knowledge continually and every time when there is stimulation, used to be able to understand and interpret a variety of symptoms, events and objects that exist in a cultural environment that was also owned by the society in which he lives. Furthermore, culture has a role as a framework for understanding the handle. So with the human culture has the ability to realize certain behavior in accordance with the stimuli that exist or are being faced.

Culture is like a recipe in cooking, which can result in behavior and certain cultural objects, as required in accordance with the stimulus or motivation of facing. The recipes that exist in every culture consists of a series of instructions for organizing, selecting and assembling the symbols necessary, so that the symbols have been screened it together and arranged in a way, is manifested in the form of behavioral or cultural objects as desired by the perpetrators. Besides, in every culture there is also a prescription-resp which among other things contains the knowledge to identify the goals and ways to achieve something with the best. ${ }^{24}$

\footnotetext{
${ }^{23}$ Clifford Geertz, The Interpretation of Culture (New York: Basic Books, 1973).

${ }^{24}$ J.P Spradley, Anthropology: The Cultural Perspective (USA: John and Sons, Inc, 1975).
} 
Culture valid and exist in every aspects of life. As culture prevailing at SMK Plus Nurul Ulum. The prevailing culture at this school is applying boarding culture. As we know the Islamic boarding school is an educational institution with Indonesian characteristics. In other Islamic countries there is no institution that has the characteristics and traditions exactly as boarding schools, although there may be certain educational institutions in other countries are considered to have similarities with schools like Ribath, Sakan Dakhli or Jam'iyyah.

Pesantren is a system of Islamic education in Indonesia, which has demonstrated its role to contribute no little to the development of human beings. Boarding institution is also an Islamic educational institution that owns the lodge, the mosque, the students, the teaching of classical Islamic books, and clerics.Saleh ${ }^{25}$ states that schools meupakan joint institute between the lodge and boarding system (traditional) and is equipped with a formal education in the form madrassas, even public schools in various forms and levels and a variety of vocational according to the needs of the individual.

Pesantren is a typical Indonesian educational institutions that since 2002 received special attention in the eyes of the world marked by a bomb blast in Kuta, Bali which is likely to come from Islamic groups such as $\mathrm{Al}$ Qaeda's most famous ${ }^{26}$ but the nickname for the group in Indonesia is Jemaah Islamiyah. Of the incident, Pohl ${ }^{27}$ illustrates that the boarding school is a means or a place to nurture and

${ }^{25}$ Abdur Rahman Saleh, Pendidikan Agama dan Keagamaan (Jakarta: PT Gemawindu Panen Perkasa, 2000).

${ }^{26}$ Vedi R Hadiz, "Towards a Sociological Understanding of Islamic Radicalism in Indonesia," Journal of Contemporary Asia 38, no. 4 (2008), 638-47.

${ }^{27}$ Florian Pohl, "Islamic Education and Civil Society: Reflections on the Pesantren Tradition in Contemporary Indonesia," Comparative and International Education Society 50, no. 3 (2006), 389-409. 
foster an attitude of radicalism and violence. In line with the above Pohl,Bruinessen ${ }^{28}$ also describes as a place to print boarding humans who have a radical nature. He said that lately pesantren in Indonesia has a poor image in the eyes of the general public, such as boarding schools in India and Pakistan. Furthermore, he explained more in that boarding school is one of the parties who contribute and play a role in the issue of radicalism and terrorism. Opinion of the above suggests that Islam also contributed in terms of politics, but political Islam in question is in terms of radicals. Radical political Islam appears when the incident happened at the World Trade Center in New York in September 2001, so that the radical politics in Islam get special attention in the eyes of the world. ${ }^{29}$

However, not all schools have a bad image as described by many figures as above. As said byMillie ${ }^{30}$ that pesantren is an institution that is useful to hone and develop skills. Pesantren actually has a role and contribute significantly to the formation of the nation of Indonesia. pesantren had been providing tangible evidence of commitment to the nation although reciprocity in kind not yet fully given to the government. Pesantren under the auspices of NU (Nahdlatul Ulama) in particular has proven its role in the struggle for independence through physical struggles and anti-colonial statement as envisaged in resolution jihad issued in $\mathrm{NU}$ congress in Surabaya, 21 and 22 October 1945. Pondok Pesantren has also shown its role in maintaining political

\footnotetext{
${ }^{28}$ Martin van Bruinessen, “'Traditionalist' and 'Islamist' pesantrens in Indonesia," dalam The Madrasa in ASLA, Transnational Linkages and Alleged or Real Political Activities, 2004. Indonesia."

${ }^{29}$ Hadiz, "Towards a Sociological Understanding of Islamic Radicalism in

${ }^{30}$ Julian Millie, "Non-Specialists in The 'Pesantren': The Social Construction of Islamic Knowledge," RIMA: Review of Indonesian and Malaysian Affairs 42, no. 1 (2008): 107-24.
} 
stability through recognition and acceptance of Pancasila as the sole principle in the organization as represented.

Pesantren an Islamic institution which mengajarakan on religious and religious sciences, and not a few who mengajarakan about the sciences of a general nature. But mostly, mengajarakan schools and providing education in the field of religion. SMK Plus Nurul Ulum boarding role as owner of a foundation headed by a Kyai/Ustadz named KH. Hanief Abdul Razaq along with his wives, named Mrs. Hj. Lailiatul Ainiyah. SMK Pesantren Nurul Ulum Plus is a breath of spring boarding more modern. Breath that adorn modern semi boarding is intended to strike a balance between the traditional boarding schools with modern pesantren. So these schools are not in full traditional and modern are not intact.

Nurul Ulum boarding establishments purpose initially was to create a whole man of faith and piety to God Almighty, and has a good attitude and morals, manners to people who are older and know the Islamic Shari'ah, beneficial to society or the community submissive to becoming a servant or a public servant as well as a steward for the community, able to stand alone, free and steadfast in the establishment, spread or enforce Islamic religion and the glory of the Muslims in the middle of the community and love of science in order to develop the personality of Indonesia.

However, in line with the change of time, Nurul Ulum boarding does not change direction initially. However, he added that initially only the bow inclined towards religious science in this case is added with teaching general sciences such as skills and knowledge of the other. With the establishment of vocational Plus Nurul Ulum then bow Nurul Ulum boarding schools that are grown to semimodern. In SMK Plus Nurul Ulum not be separated entirely 
from the culture which is becoming a basic boarding primary schools to introduce them. Base boarding school that has surrounded this makes the school has an additional mission in a variety of subjects and learning techniques. In the school did not like the other schools that are not based schools. Plus SMK Nurul Ulum add keagaamaan appropriate knowledge and learning in schools, such as knowledge of the Arabic language, History of Islamic Civilization, esktrakurikuler like books of Islamic studies exception yellow book that was obtained by the student from the school. With the existence of such schools in addition to scoring proficient Muslim intellectuals but also can produce good Muslims with understanding andrules in accordance with the rules of Islamic religious behavior and can result in Muslims who have a strong commitment to religion. ${ }^{31}$

Bruinessen ${ }^{32}$ say that boarding schools are not the only institutions to gain knowledge about the religion of Islam, but there are also others such as surau, schools, and mosques. So it is now SMK Plus Nurul Ulum with schools that exist today work in synergy to strengthen and maintain the institution in order to accomplish the mission that has aspired to the functions of pesantren not only generate Muslims who do not have intellectuality high, but instead that Muslims have versatility in terms of religion as well as in terms of intellectuality. So also with the function of SMK Plus Nurul Ulum itself embraced from the beginning that not only produces proficient intellectuality Muslims without religion, but on the contrary that produces proficient Muslim

${ }^{31}$ Jackson Elisabeth, "Enriched with Knowledge': Modernisation, Islamisation and the Future of Islamic Education in Indonesia," RIMA: Review of Indonesian and Malaysian Affairs 42, no. 1 (2008): 21-53.

${ }^{32}$ Martin van Bruinessen, Pesantren and Kitab Kuning: "Maintance and Continuation of a Tradition of Religious Learning", in: Wolfgang Marschall, Texts From The Islands. Oral and Written Traditions of Indonesia and The Malay World [Ethnologica Bernica,4] (Berne: University of Berne, 1994). 
intellectual and religious. Because according toTan, ${ }^{33}$ most schools in Indonesia is keen to gain knowledge of the subjects that is religious and general subjects.

Plus culture in vocational schools Nurul Ulum was originally a boarding school culture are in traditional/ classic. Ketradisionalan elements that appear in traditional pesantren is synonymous with classic books that are used as a source for learning one dalah use yellow books as a typical depiction Indonesian pesantren. Yellow book, is a book or books used by students (the nickname of the students who are studying in boarding schools) to learn.Bruinessen ${ }^{34}$ mention the use of the yellow book to learn the students began the implementation of the curriculum schools in 1886. More profound Bruinessen ${ }^{35}$ also explained that the yellow book is a collection of classical texts from various disciplines in Islam written within the period of centuries. Furthermore, he explained that the yellow book until now used as a tradition of learning at the school who is calling for a traditional transmission, especially in Java and the Malay Peninsula. While the teaching methods used are also teaching methods are archaic and classic like sorogan, wetonan, and bandongan.

\section{Patterns of Interaction Among Students At SMK Plus Nurul Ulum}

Social interaction is social relations dynamic regarding the relationship between individuals, between groups of

\footnotetext{
${ }^{33}$ Charlene H.P (Chalene Hwee Phio) Tan, "Educative tradition and Islamic schools in Indonesia," Journal of Arabic and Islamic Studies 14 (2014): 47-62.

${ }^{34}$ Martin van Bruinessen, "Kitab Kuning: Books in Arabic Script Used in The Pesantrean milieu; Comments on a New Collection in The KITLV Library," In: Bijdragen tot de Taal-, Land-en Volkenkunde 146, no. 2/3 (1990): 226-69.

${ }^{35}$ Bruinessen, Pesantren and Kitab Kuning : "Maintance and Continuation of a Tradition of Religious Learning", in: Wolfgang Marschall.
} 
people, as well as among individuals with human groups. ${ }^{36}$ Social interaction is useful to examine and learn a lot of problems in society. Social interaction is the key to all social life because without social interaction would not be out of the joint.

Social interaction is established in the body SMK Plus Nurul Ulum. Interaction is done between students and students, teachers and students and teachers with other teachers. Interaction is done by students and students of SMK Plus Nurul Ulum against fellow students and to the teachers as well as the owner of the foundations can be quite good. Every day they make the process of social interaction in order to maintain the communication to the activity in line with expectations.

The interaction process that runs in vocational Plus Nurul Ulum is not bound by anything. They are free to interact with anyone whether it's with girls or boys even though they are in a boarding school environment without any restraint. But they still pay attention to the norms in force and framing boarding schools. This usually happens during especially in boarding schools at the center of the village, students rarely women and men are allowed to interact even in formal studies such as school or religious studies. Because according to the religion of Islam does not allow Kyai between men and women greeting bertinteraksi. It is based on the teachings of Islam which does not allow for any group to interact if not a relative. So, Most schools are located in the interior village was established as a form of reaction to certain life patterns that are considered vulnerable. But this time, the presence of schools like that enveloped CMS Plus Nurul Ulum that is different from the others is one part of a

${ }^{36}$ Gillin Gillin, Cultural Sociology, a Revision of an Introduction to Sociology (New York: The Macmillan Company, 1954). 
cultural transformation that is running in the long term, but still maintain the ethics that have been attached to it that is guided towards religion, but applied to the point proper.

In their daily lives at school, they do not care about the historical background attached to and carried by their respective friends. Anyone who wants to say hello and want to talk, they respond immediately without thinking long in advance as to whether they should menggubris or not for various reasons. This pattern of interaction as they do every time, when they met each other at recess or before learning begins.

Interaction is good as well they do when being in one room school assemblies consultative organizations such as student council. Together they interact with other members of the organization to exchange opinions. There was no one who was exiled as not invited to speak, by reason of his opinions later is not useful and does not correspond to the subject. This is in accordance with the word of the Prophet Muhammad bahwasannya not justified if there are more than two people among a collection of human beings, then they speak in a whisper without inviting others to speak, because acts like this will only hurt the feelings of people who are not invited to speak.

The next interaction patterns they did when the hour course starts, the interaction with the system of mutual cooperation. Such as in learning activities they undertake the process of discussion between friends and groups requested by the teacher concerned. With this mutual aid system they will be easier to solve the problem as provided by the subject teachers because in it there is some sort of interaction efforts made by members of the group to donate another argument with the aim of solving the existing problems. 
Interaction patterns shown by the students and students of SMK Nurul Ulum orphanage Jember Plus can be said as one manifestation of fraternal relations which they intertwine as a result of the attitude of tolerance among peers. So that the pattern of interaction that exists either by their rarely touched by viruses such as the central conflict rife in other schools that are in Jember.

Figure 1. Interaction of students when having group discussion

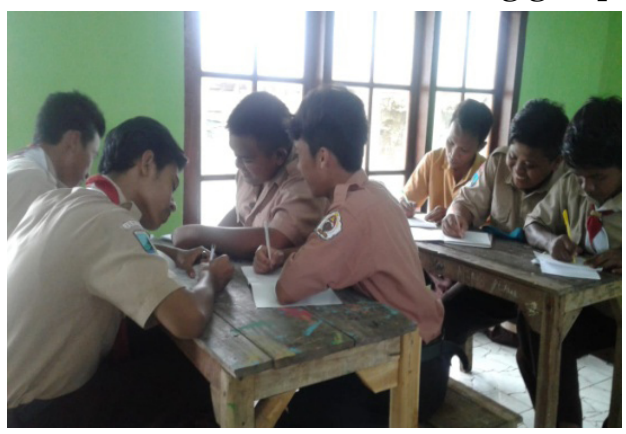

Figure 2. The harmony between teachers and students

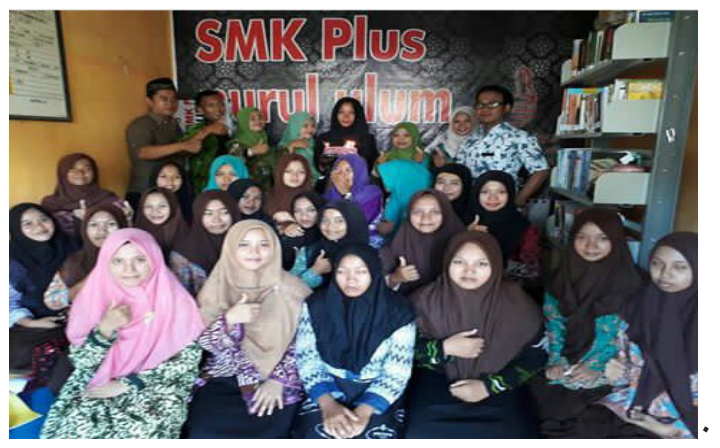

\section{Tolerance Attitudes on Student Religious IdeologyAt SMK Plus Nurul Ulum}

Religious, ethnic and other social groups as an instrument of social plurality Indonesia could become a crucial issue for the process of social integration. In a context such as this, an understanding of each individual every human being affect the realization of tolerance between communities. 
Differences in religious sects and tribes in the midst of the social life of students and students of SMK Plus Nurul Ulum make their hearts want to maintain the integrity together because of the diversity. They realize that they live in a school which consists different persons. Togetherness is something that most guarded by them, because they do not want a split in the middle. By looking at the existing situation, students' mindsopen to create mutual respect each other and accept each other for the various differences without picking and sorting.

The concept of their attitude in accepting the contradictions that they pour in tolerance. Which tolerance can be said as a gesture reflecting the change in the individual which allow their willingness to accept things that are contradictory of himself. ${ }^{37}$ In line with thisReese ${ }^{38}$ argued that tolerance is an attitude that depict the harmonious relationship that occurs in a community which involves a series of diverse community members. This means that tolerance is an important element that must be built for tolerance is necessary for the body of a heterogeneous society especially to people who are liberal. ${ }^{39}$

Adding a sense of tolerance, according to Advanced Learners Dictionary of Current English, tolerance tends Quality of tolerating opinions, beliefs, customs, behaviors etc, which means membiarkanm attitude, recognizing and

${ }^{37}$ Thomas C Wilson, "Trends in Tolerance Toward Rightist and Leftist Groups, 1976-1988: Effect of Attitude Change and Cohort Succession," Journal of American Association for Public Opinion Research 58, no. 4 (1994), 539-56.

${ }^{38}$ Laura A Reese, "Substantive and Procedural Tolerance: Are Diverse Communities Really More Tolerant?," Journal of Urban Affairs Review 51, no. 6 (2014), 781-818.

${ }^{39}$ Ryan Muldoon, “The Condition of Tolerance," Journal of Politics, Philosophy and Economics 11, no. 322-244 (2011). 
respecting the beliefs of others without requiring approval. ${ }^{40}$ Meanwhile, according to the New Americans Webster Dictionary defines tolerance by giving free expression (let) the opinions of others and apply patience with others.

According to male and female students of SMK Plus Nurul Ulum tolerance is very important to be built in the hearts and attitudes. The reason they build tolerance is tolerance of a lunge that feels greatly affect supplies in the joints of the lead amongst the people who have the diversity and difference because tolerance is a mediation that can be used to settle a problem. In accordance with the opinion of Kinloch ${ }^{41}$ who say that tolerance is the way to resolve the conflict in the social interaction between several warring parties without sacrificing any of the parties. In line with the above opinion, Fatkhuri ${ }^{42}$ said that a culture of tolerance among all men is urgent and a dream for every human circle for the creation of a harmonious life among them.

Sometimes tolerance arises unconsciously and unplanned, which due to the nature of individual or groups of people wherever possible to avoid a dispute. But unlike the male and female students in vocational Plus Nurul Ulum Jember. Framing tolerance they were born not because the action is unconscious or unplanned, but they actually planned the birth and the presence of tolerance in the midst of their days at school to deliberately avoid the birth of a dispute among friends of different religions.

Tolerance to the ideology of religion is fundamental to act early and male and female students of SMK Plus Nurul

${ }^{40}$ A.S Hornby, Oxford Advanced Learners Dictionary of Current English (London: Oxford University Press, 1986).

${ }^{41}$ Graham C Kinloch, Sociological Theory: Development and Major Padigm (Bandung: Pustaka Setia, 2005).

${ }^{42}$ Fatkhuri, Toleransi Beragama di Daerah Rawan Konflik (Jakarta: Kementerian Agama RI Badan Litbang dan Diklat Puslitbang Kehidupan Keagamaan, 2016). 
Ulum as early learning material for their further develop the attitude of tolerance towards their fellow human beings. Religious tolerance that has meaning and gracefully accepting attitude towards everything that is done by another religion without having to force myself to obstruct an attitude that they woke up today. The reason the construction of tolerance by male and female students of SMK Plus Nurul Ulum against religious sects is that they assume that the ideology of the religion they hold today is not necessarily true. Many other religious sects that more true than religious sects they believed in even though they are both derived from Islam.

Concepts such as these they built with attention to many of the principles contained in the religion and culture of indigenous ancestors (the local culture Jember) the culture Pendhalungan Jember to adopt cultural values held as an umbrella in creating an attitude of religious tolerance for male and female students of SMK Plus Nurul Ulum Jember. Here will be described the umbrella of religious tolerance attitude they used to be tolerant based on the teachings of the Islamic religion and local culture that eventually became a hood for students and students of SMK Plus Nurul Ulum in creating tolerance towards religious stream school.

\section{a. Teachings of Islam}

Religion is a guidance or instructions for living in the truth according to God's determination. In the Islamic tradition, addin or religion is defined as an indication of God that encourages heart reasonable person to follow with its own ikhtiarnya for their welfare and happiness in the next world.Ortner ${ }^{43}$ describes pegertian religion that religion is a system of explanation with cognitive anthropology and as a

${ }^{43}$ S Ortner, "Theory in Anthropology Since The Sixties." Comparative Studies in Society and History 26, no. 1 (1984): 126-66. 
theory of practice. WhileDurkheim ${ }^{44}$ explain about religion that religion is a symbolic system that pointed to social organizations. Religion has tremendous strength in bringing together people from various backgrounds foam, ethnicity, tribe, religion and other sendii, but the other religion can also be a cause of conflict which in turn will undermine social harmony.

Religion Islam is a religion that rahmatan lil'alamin, referring to the Islamic religion that was born in this world bring grace and a great gift to mankind so that from there to bring peace and prosperity to the people and people can avoid conflicts both vertically and horizontally. In line with it,Karim ${ }^{45}$ argue that Islam is a divine religion revealed by God that all the teachings contained in the Qur'an and Sunnah in the form of commands, prohibitions, and instructions for the good of human kind in the world and the hereafter.

In Islam, the concept of tolerance has been described by the word of Allah in the Qur'an that QS. Al Kafirun that have a meaning that everyone has the right to worship their God in accordance with the beliefs of their religion respectively, because every religion has a God worthy of their trust and cherished, and not allowed for any religion to force people of different religions to into religion. Thus, in Islam of tolerance can easily support the ethical difference. In line with the explanation, in the Quran surah Al Baqoroh paragraph 256 explains that is not allowed for anyone mankind to force another human being to enter into a world religion because it is already apparent difference-perbdaan that was deliberately created by God.

Islam has been recognized as a religion that is fighting for justice, fraternity, and equality among peoples. This is in

\footnotetext{
${ }^{44}$ E Durkheim, The Elementary Forms of Religious Life (New York: Collier, 1911).

${ }^{45}$ M Abdul Karim, Islam Nusantara (Yogyakarta: Gama Media, 2013).
} 
accordance with the word of Allah in Surah. An-Najm 39 who mean the balance between the individual and society. The point is that the religion of Islam calls upon mankind that in life we should recognize the existence of man as an individual and assume everyone has a personal responsibility to God, even in the religion of Islam guarantee human rights of individuals and do not allow any interference from anyone else in it. However, why this world is still raised many conflicts caused by religious conflict? Yet it is clear that religion teaches us to be good by the basic virtues of behaving. The right answer to this question is the existence of a false understanding of the existing denominations. A religious mission to bring mercy to all the worlds reduced by a narrow understanding. Any religious streams are difficult to dialogue and co-exist with social and cultural developments so that any existing religious sects become clumsy and stiff dealing with pluralism and multiculturalism, while multiculturalism and pluralism is part of religious teachings.

The phenomenon of inter-religious conflict is the brainchild of an exclusive religious paradigm, superior and considers religion Paing right. This attitude is clearly fueled the prolonged religious conflicts are not only tarnishing agam stream to another, but also tarnish the ideology of their own religion.

Religion Islam encourages men to have the nature of good and generous for the good of themselves and others, although different in religion from him. In the Islamic religion there is a doctrine which says that "a person's faith will not be perfect if she did not love others as he loves himself". This implies that man should first care about other people who are around, rather than care for themselves without looking around him. However, it should be noted that, the tolerance 
taught by every religion can not stand alone but is influenced by other factors such as political, social, and economic.

Indonesia is a nation inhabited by people with different religious backgrounds, ethnic, and social groups are diverse. Pluralism is an incontrovertible reality of this archipelago on earth. One hand, this plurality of social capital development of the nation and on the other hand be a latent potential for social conflict.

Conception and inter-religious harmony are two forms inseparable from each other. There, there is a causality that surrounds them. Concord have an impact on tolerance and vice versa tolerance have a huge impact for the creation of harmony. So both concerning the relationship among humans. There are three basic relationships that create harmony between every human being different on each side of the internal race in religion and religious communities with the government woke up and hidupdan applications on everyday life, then there will be tolerance among humans.

Tolerance towards religious stream that has been applied by the students and students of SMK Plus Nurul Ulum, reflect on some of the concepts contained in the religion of Islam as described above. Because, according to them in accordance with the teachings of the Islamic religion that does not justify coercion in matters of religion, so that religion should not be forced upon anyone. People are entitled to pick and choose the religion they believe in. As the opinions expressed byCassanova ${ }^{46}$ who said that freedom of religion is a thing to reconsideration by every human rights that exist in this world. Ditersebut opinion was

${ }^{46}$ See Jose Cassanova, "Private and Public Religion," Journal of Sosial Search 59, no. 1 (1992): 17-57. 
reinforced byMaula ${ }^{47}$ who said that one of the human rights is to determine and choose the religion they deem most correct because it is a form of manifestation of someone in upholding human rights.

Similarly, the male and female students in vocational school, they did not force her to get into the ideology of the religion which is owned by each individual, because as mentioned earlier religious sects believed by each individual is not necessarily true and good, because there are many outside there of religious sects which are much better than they trust religious sects today. So it can be said to be taboo when they proudly extolling religious stream and ask schoolmates to sign and membenarakan teachings of religious sects owned by each student.

\section{b. Cultural Values Pendhalungan}

Tolerance built by students and students of SMK Plus Nurul Ulum has a very strong runway. In addition they pay attention to the various concepts of the Islamic religion in building an attitude of tolerance, they also pay attention to the culture around which also helped contribute to the diversity that characterizes SMK Plus Nurul Ulum.

Pendhalungan cultural value is the next cornerstone that they use to create the attitude of religious tolerance in schools. Hindaryatiningsih ${ }^{48}$ explains that every culture has its own cultural values as a basic virtue. In line with the above opinion.Musaddad $^{49}$ also revealed that the integration of

${ }^{47}$ Bani Syarif Maula, "Religious Freedom in Indonesia: Between Upholding Constitutional Provisions and Complying With Social Consideration," Journal of Indonesian Islam 7, no. 2 (2013), 383-403.

${ }^{48}$ Nanik Hindaryatiningsih, "Process Model Inheritance Value-value of Local Culture in Society Tradition Buton," Journal of Social Sciences and Humanities 18, no. 2 (2016), 108-15.

${ }^{49}$ Akhmad Arif Musaddad, “The Reinforcement of Dharma Gita Bali Values in Historical Learning to Improve Students Tollerance Attitude," International Journal of Multicultural and Multireligious Understanding 5, no. 2 (2018). 
values such as cultural values it can dig tolerance students. Reflecting on it, Pendhalungan culture has virtues that could serve as the basis and provision landasar life by pupils and students of SMK Plus Nurul Ulum. Values that are born from a culture Pendhalungan such as solidarity, tolerance, mutual aid, social care, and so forth is something that is very important for students and senior high school students Nulum doing things such as acting, taking actions and decisions, as well as addressing a problem that will have implications for the creation of a harmonious life away from conflicts.

The real value is something abstract but can be used as guidelines in behaving. Humans without value will not be able to live a real life, because real humans have very close ties with the value that humans can achieve the goal of his life. Value is also an urgent matter for humans as serve as a set of beliefs that influence human attitudes and behavior. Male and female students of SMK Plus Nurul Ulum use as a filter value in the act. While there are of most students have eliminated the noble values rooted both in culture. However, one if they eliminate the noble values of a culture that has a moral message that is very good for their future.

Suparlan ${ }^{50}$ explain that cultural values are guidelines for people in a civilized, as can know that truth is the opposite of wrong, opponents of dirty clean, beautiful opposed to bad, and so on. In line with this, Sartini ${ }^{51}$ said that the value of the local culture actually contains a wide range of philosophy, philosophy of life and ethics that can serve as guidelines for balancing the journey of life in this heterogeneous country. In accordance with the statement described above means that

${ }^{50}$ Parsudi Suparlan, "Bhineka Tunggal Ika: Keanekaragaman Suku Bangsa atau Kebudayaan," Jurnal Antropologi Indonesia 72, no. 1 (2003), 29-37.

${ }^{51} \mathrm{Ni}$ Wayan Sartini, "Mengali Nilai Kearifan Lokal Budaya Jawa Lewat Ungkapan (Bebasan,Saloka dan Paribasa)," Jurnal Ilmiah Babasa dan Sastrav, no. 1 (2009), $28-37$. 
the value contained in the culture can deliver Pendhalungan especially humans in life to reach the goal of his life. No wonder students and students of SMK Plus Nurul Ulum choose Pendhalungan cultural values as an umbrella to two for their use as pajamas to tolerate religious stream in the school.

One Pendhalungan cultural values that serve as the hood in being tolerant is the value of tolerance. As explained previously associated with tolerance, bahwasannya tolerance is really necessary era of mature nowadays, especially for students and students of SMK Plus Nurul Ulum notabenenya is a student who has a historical background and ideology of different religions so that they can live harmony and peace together with his friends who are within the scope of the same school.

The reason for choosing Pendhalungan especially its cultural values on the values of tolerance by male and female students of SMK Plus Nurul Ulum orphanage is they want to do not forget the roots of the origin itself. In addition, they also found his grandmother's ability to live in harmony and peace in Jember also armed with the tolerance values that exist in this Pendhalungan culture. So they decided to adopt a tolerance values of cultural heritage Pendhalungan Jember to serve as covering their hearts are tolerant of religious sects that exist.

The ability of male and female students of SMK Plus Nurul Ulum orphanage to have an attitude of mutual respect and respect (tolerance) to the ideology of religion in schools is a matter that can be said to be wise in dealing with some problems in diversity. They bring the attitude of religious tolerance in the midst of learning is something that is not easy to do by their age, which most kids their age are still with asiknya swim dive into the ocean teenage years are filled 
with frenetic without considering others that exist around, So that students their age rarely ignore social attitudes that have an impact in life.

\section{Conclusion}

Plus SMK Nurul Ulum is based boarding school located in the village of Panti subdistrict Kemuningsari Jember Lor. Vocational schools that decorate the base Plus Nurul Ulum said boarding schools are semi-modern.

Plus SMK Nurul Ulum is a school that had students the historical background and the different streams of religion. The school is decorated by the diversity of the students were able to create a very good attitude and commendable that the attitude of tolerance. Tolerance which created not on the initiative by the teacher or the school authority stakeholders, but tolerance is built in the body SMK Plus Nurul Ulum was born on the initiative of the students and its students. The birth of this tolerant attitude background by the diversity among students as the historical background and religious sects which are in one room that is SMK Plus Nurul Ulum. Of diversity that they wished for the conflicts created as is now often the case.

Their basis in mencitpakan tolerance in schools that is based on the teachings contained in the Islamic religion and cultural values Pendhalungan which they very well to be adopted as early guidance in the birth of a tolerant attitude. And proven armed in either case it creates a tolerant attitude among different students so that they can be regarded as boys and girls who are wise in action and appreciate the other man, although different from himself. 


\section{REFERENCES}

Bahrudin, Moh. "Peran Ulama Nahdlatul Ulama Dalam Menyiarkan Paham Keagamaan Moderat Di Provinsi Lampung." Jurnal Analisis 17, no. 12017

Barton, Greg. Gagasan Islam Liberal Indonesia. Jakarta: Paramidana dan Pustaka Antara, 1999.

Basuki, A Singgih. Agama-agama Dunia: Agama Primitif. Yogyakarta: Jurusan Perbandingan Agama UIN Sunan Kalijaga Yogyakarta, 2012.

Beritajatim.com. "Waspadai Dakwah Intoleran, MUI Jember Segera Temui GP Ansor,” 2018.

Bruinessen, Martin van. "Genealogies of Islamic Radicalism in Post-Suharto Indonesia." South East Asia Research 10, no. 22002.

. "Kitab Kuning: Books in Arabic Script Used in The Pesantrean milieu; Comments on a New Collection in The KITLV Library." In: Bijdragen tot de Taal-, Land-en Volkenkunde 146, no. 2/3 1990.

. Pesantren and Kitab Kuning: "Maintance and Continuation of a Tradition of Religious Learning", in: Wolfgang Marschall. Texts From The Islands. Oral and Written Traditions of Indonesia and The Malay World [Ethnologica Bernica,4]. Berne: University of Berne, 1994.

.'Traditionalist' and 'Islamist' pesantrens in Indonesia." Dalam The Madrasa in ASLA, Transnational Linkages and Alleged or Real Political Activities, 2004.

Bush, Robbin. Nabdlatul Ulama and The Struggle for Power Within Islam and Politics in Indonesia. Singapore: ISEAS Publishing, 2009. 
Cassanova, See Jose. "Private and Public Religion." Journal of Sosial Search 59, no. 11992.

Durkheim, E. The Elementary Forms of Religious Life. New York: Collier, 1911.

Eisenstadtd, S.N. modernization: protest and change. englewood cliffs: prentice-hall, 1966.

Elisabeth, Jackson. 'Enriched with Knowledge': Modernisation, Islamisation and the Future of Islamic Education in Indonesia." RIMA: Review of Indonesian and Malaysian Affairs 42, no. 1,2008.

Fatkhuri. Toleransi Beragama di Daerah Rawan Konflik. Jakarta:

Kementerian Agama RI Badan Litbang dan Diklat Puslitbang Kehidupan Keagamaan, 2016.

Gagaje. "Surat Al Kafirun Lengkap Dengan Terjemahan dan Artinya.” gagaje.blogspot.com, 2013. http://gagaje. blogspot.com/2013/05/surah-al-kafirun.html.

Geertz, Clifford. The Interpretation of Culture. New York: Basic Books, 1973.

- The Religion of Java. III. Glencoe: The Free Press, 1960.

Gillin, Gillin. Cultural Sociology, a Revision of an Introduction to Sociology. New York: The Macmillan Company, 1954.

Hadiz, Vedi R. "Towards a Sociological Understanding of Islamic Radicalism in Indonesia." Journal of Contemporary Asia 38, no. 4, 2008.

Hernawan, Wawan. "Social Prejudice In Religious Plurality At Cigugur District Regency of Kuningan West Java." Journal of Social Sciences and Humanities 19, no. 1, 2017.

Hindaryatiningsih, Nanik. "Process Model Inheritance Valuevalue of Local Culture in Society Tradition Buton." Journal of Social Sciences and Humanities 18, no. 2, 2016. 
Hodgson, M. The Venture of Islam. Conscience and History in a World Civilization. Disunting oleh University of Chicago Press. Chicago, 1974.

Hornby, A.S. Oxford Advanced Learners Dictionary of Current English. London: Oxford University Press, 1986.

Ismail, Faisal. "The Nahdlatul Ulama Its Early History And Contribution To The Establishment of Indonesian State." Journal of Indonesian Islam 05, no. 02, 2011.

Jinan, Mutohharun. "Muhammadiyah Studies: Transformasi Kajian Tentang Gerakan Islam di Indonesia.” Analisa Journal of Social Science and Religion 22, no. 02, 2015.

Karim, M Abdul. Islam Nusantara. Yogyakarta: Gama Media, 2013.

Kinloch, Graham C. Sociological Theory: Development and Major Padigm. Bandung: Pustaka Setia, 2005.

Kompas.com. "MUI: 2013, Lima Konflik Keagamaan Terjadi Di Jember,” 2013.

Maula, Bani Syarif. "Religious Freedom in Indonesia: Between Upholding Constitutional Provisions and Complying With Social Consideration." Journal of Indonesian Islam 7, no. 2, 2013.

Millie, Julian. “Non-Specialists in The 'Pesantren': The Social Construction of Islamic Knowledge." RIMA: Review of Indonesian and Malaysian Affairs 42, no. 1. 2008.

Muldoon, Ryan. "The Condition of Tolerance." Journal of Politics, Philosophy and Economics 11, no. 322-244, 2011.

Musaddad, Akhmad Arif. "The Reinforcement of Dharma Gita Bali Values in Historical Learning to Improve Students Tollerance Attitude." International Journal of Multicultural and Multireligious Understanding 5, no. 2, 2018. 
Nakamura, Mitsuo. "The Radical Traditionalism of the Nahdlatul Ulama in Indonesia : A Personal Account of the 26th National Congress, June 1979, Semarang." South East Asian Studies 19, no. 2, 1981.

Ortner, S. "Theory in Anthropology Since The Sixties." Comparative Studies in Society and History 26, no. 1, 1984.

Pohl, Florian. "Islamic Education and Civil Society: Reflections on the Pesantren Tradition in Contemporary Indonesia." Comparative and International Education Society 50, no. 3, 2006.

Reese, Laura A. "Substantive and Procedural Tolerance: Are Diverse Communities Really More Tolerant?" Journal of Urban Affairs Review 51, no. 6, 2014.

Rogers, Everett M. Modernization Among Peasants: The Impact of Communication. New York: Holt, Rinehart, and Winston, 1976.

Rohman, Abdul. "Persepsi Kelompok Syahadatain Terhadap Nilai-nilai Toleransi Di Kabupaten Banyumas." Jurnal Analisa XVIII, no. 2, 2011.

Sairin, Sjafri., Prof., Dr. Perubahan Sosial Masyarakat Indonesia: Perspektif Antropologi. Yogyakarta: Pustaka Pelajar, 2002.

Saleh, Abdur Rahman. Pendidikan Agama dan Keagamaan. Jakarta: PT Gemawindu Panen Perkasa, 2000.

Sartini, Ni Wayan. "Mengali Nilai Kearifan Lokal Budaya Jawa Lewat Ungkapan (Bebasan,Saloka dan Paribasa)." Jurnal Ilmiah Bahasa dan Sastra v, no. 1, 2009.

Sobary, Mohamad. NU DAN KEINDONESIAAN. Jakarta: Gramedia Pustaka Utama, 2010.

Spradley, J.P. Anthropology: The Cultural Perspective. USA: John and Sons, Inc, 1975. 
Suparlan, Parsudi. "Bhineka Tunggal Ika: Keanekaragaman Suku Bangsa atau Kebudayaan." Jurnal Antropologi Indonesia 72, no. 1, 2003.

Tan, Charlene H.P (Chalene Hwee Phio). "Educative tradition and Islamic schools in Indonesia." Journal of Arabic and Islamic Studies 14, 2014.

VOA-Islam.com. "Habib Zein Alkaf: Bentrok Di Jember adalah Konflik Sunni vs Syi'ah,” 2013.

Wilson, Thomas C. "Trends in Tolerance Toward Rightist and Leftist Groups, 1976-1988: Effect of Attitude Change and Cohort Succession." Journal of American Association for Public Opinion Research 58, no. 4, 1994.

Woodward, Mark R. Islam Jawa. I. Yogyakarta: LKS Yogyakarta, 1999. 